\title{
Monitoring B-cell repopulation after depletion therapy in neurologic patients
}

Erik Ellwardt, MD, Lea Ellwardt, PhD, Stefan Bittner, MD, and Frauke Zipp, MD

Neurol Neuroimmunol Neuroinflamm 2018;5:e463. doi:10.1212/NXI.0000000000000463
Correspondence

Dr. E. Ellwardt

erik.ellwardt@unimedizin-mainz.de

\section{Abstract}

\section{Objective}

To determine the factors that influence B-cell repopulation after B-cell depletion therapy in neurologic patients and derive recommendations for monitoring and dosing of patients.

\section{Methods}

In this study, we determined the association of body surface area (BSA; calculated by body weight and height with the Dubois formula), sex, pretreatment therapy, age, CSF data, and white blood cell counts with the risk and timing of B-cell repopulation, defined as $1 \% \mathrm{CD} 19^{+}$ cells (of total lymphocytes), following $87 \mathrm{~B}$ cell-depleting anti-CD20 treatment cycles of 45 neurologic patients ( 28 women; mean age $\pm \mathrm{SD}, 44.5 \pm 15.0$ years).

\section{Results}

Patients with a larger BSA had a higher probability to reach $1 \% \mathrm{CD} 19^{+}$cells than those with a smaller BSA $(p<0.05)$ following B-cell depletion therapy, although those patients had received BSA-adapted doses of rituximab $\left(375 \mathrm{mg} / \mathrm{m}^{2}\right)$. Sex, pretreatment, age, CSF data, or absolute lymphocyte and leukocyte counts during treatment did not significantly influence $\mathrm{CD} 19^{+} \mathrm{B}$-cell recovery in the fully adjusted models. Intraindividual B-cell recovery in patients with several treatment cycles did not consistently change over time.

\section{Conclusions}

B-cell repopulation after depletion therapy displays both high inter- and intra-individual variance. Our data indicate that a larger BSA is associated with faster repopulation of B cells, even when treatment is adapted to the BSA. A reason is the routinely used Dubois formula, underestimating a large BSA. In these patients, there is a need for a higher therapy dose. Because B-cell count-dependent therapy regimes are considered to reduce adverse events, B-cell monitoring will stay highly relevant. Patients' BSA should thus be determined using the Mosteller formula, and close monitoring should be done to avoid resurgent $\mathrm{B}$ cells and disease activity.

\footnotetext{
From the Focus Program Translational Neurosciences (FTN) and Immunology (FZI) (E.E., S.B., F.Z.), Rhine Main Neuroscience Network (rmn ${ }^{2}$ ), Department of Neurology, University Medical Center of the Johannes Gutenberg University Mainz; and Institute of Sociology and Social Psychology (L.E.), University of Cologne, Germany. 


\section{Glossary}

BSA = body surface area; FACS = fluorescence-activated cell sorting; HR = hazard ratio; NMO = neuromyelitis optica; NMOSD = neuromyelitis optica spectrum disorder; SE = standard error.

Studies that use depleting antibodies such as ocrelizumab and rituximab have proven the clinical efficacy of targeting B cells in inflammation such as $\mathrm{MS}^{1,2}$ or neuromyelitis optica spectrum disorder (NMOSD). ${ }^{3}$ The reappearance of $\mathrm{B}$ cells in the peripheral blood correlates with increased disease activity ${ }^{4}$ and is monitored by fluorescence-activated cell sorting (FACS) analysis. Although the efficacy of B-cell targeting therapies is closely linked to sufficient depletion, a considerable heterogeneity concerning monitoring and retreatment protocols complicates their use in clinical practice. The reappearance of $\mathrm{B}$ cells can be defined when $\mathrm{CD} 19^{+}$cells reach $1 \%$ of lymphocyte counts, ${ }^{5}$ which then leads to the next treatment cycle. However, some protocols use fixed time intervals (e.g., every 6 months in clinical trials for ocrelizumab) but also $2 \%$ or absolute lymphocyte counts such as 10 per $\mu \mathrm{L}$ for $\mathrm{CD} 19^{+}$cell monitoring. ${ }^{4,6}$ Our clinical experience is that once patients reach $1 \%$, they rapidly surpass $2 \%$ within days. As an alternative approach, monitoring of $\mathrm{CD} 27^{+}$memory B cells has been suggested as a sensitive marker after rituximab treatment. ${ }^{7,8}$ Still, there is a high interindividual variance between patients who require personalized monitoring for each patient. Inconsistency exists not only concerning B-cell monitoring parameters but also dose regimens. Whereas some patients receive body surface area (BSA)-adapted doses (usually $375 \mathrm{mg} / \mathrm{m}^{2}$ ), some receive fixed doses. ${ }^{9}$

To identify factors influencing repopulation of B cells, we analyzed $\mathrm{CD} 19^{+}$cell counts of neurologic patients (aged 17-76 years) treated at least once with rituximab or ocrelizumab and examined age, sex, medical pretreatment, oligoclonal bands and cell count in the CSF before the first treatment, as well as concomitant leukocyte and lymphocyte counts and the BSA.

\section{Methods}

\section{Standard protocol approvals, registrations, and patient consents}

We identified patients in the Neurology Department at the University Medical Center Mainz, Germany, from 2007 until March 2017 who had received at least 1 infusion with rituximab or ocrelizumab. Patient data were acquired retrospectively and anonymized according to $\$ 36 / 37$ of the Rhineland-Palatinate state hospital law. Patients of the University Medical Center Mainz provided their written consent that data and remaining material can be used for research.

\section{Data acquisition}

For those patients, we collected all available $\mathrm{CD} 19^{+}$cell counts obtained by flow cytometric (FACS) analysis during treatment in our clinic. FACS data were usually acquired 3 and 6 months after the last treatment and monthly thereafter. In individual cases, close monitoring was done (e.g., if $\mathrm{CD} 19^{+}$ cells were rising already after 3 months). In this analysis, we also collected personal characteristics (e.g., age, sex, and BSA) and received information on medical pretreatments and diagnosis from medical letters and reports. The BSA had been calculated for all patients using the Dubois formula $\left(0.007184 \times\right.$ height $[\mathrm{cm}]^{0.725} \times$ body weight $\left.[\mathrm{kg}]^{0.425}\right)$ at each treatment. To compare the accuracy of the BSA calculation, we also used the Mosteller formula $\sqrt{\frac{\text { height }[\mathrm{cm}] \times \text { body weight }[\mathrm{kg}]}{3,600}}$. The data included a record of the dates for all measurements and treatments.

\section{Definition of B-cell repopulation}

B-cell repopulation was defined as the first detection of $\mathrm{CD} 19^{+}$cells above $1 \%$ of total $\mathrm{CD} 45^{+}$lymphocytes after $\mathrm{CD} 19^{+}$cell depletion as measured by FACS. The number of days between the last rituximab infusion and the detection of repopulation was calculated. This repopulation of B cells is classified as "event" throughout the article.

\section{Statistical methods}

The data were characterized by a panel structure with repeated observations per patient. Specifically, there were 45 patients, resulting in a total of 373 patient observations during the observation period. Within the entire observation period, each patient could experience the critical event of repopulation, i.e., $\mathrm{CD} 19^{+}$cells above $1 \%$ with respective treatment, multiple times. Ultimately, there were 37 patients, who together experienced the event 87 times.

The analytical procedure was 2 -fold. First, controlling for the number of treatment cycles (1st, 2nd, 3rd, and so forth), we assessed the influence of various risk factors, such as age, sex, and BSA, on the likelihood of the critical event. For this purpose, we performed Cox proportional hazards regression. Hazard ratios (HRs) below 1 indicated decreased risk of the critical event depending on a factor, whereas the HR above 1 indicated increased risk.

Second, we were interested in the time until the (re)occurrence of the event, i.e., when $\mathrm{CD} 19^{+}$cells were measured above $1 \%$. Therefore, the model only included those observations in which the critical event had occurred ( $\mathrm{n}=$ 87). We regressed the number of days since the previous treatment on age, sex, previous therapy, and BSA in a linear random effects regression model, while controlling for the number of treatment cycles. We assessed the unadjusted and adjusted effects of all risk factors in both procedures 
and performed sensitivity analyses on missing values for the BSA.

\section{Results}

\section{Cohort characteristics}

The cohort consisted of 45 patients (62.2\% female) aged between 17 and 76 years at their first treatment cycle (mean \pm SD: $44.5 \pm 15.0$ years) (table 1). The disease spectrum included mainly patients with NMOSDs and MS (figure 1A). Forty-two patients received rituximab; 3 had received ocrelizumab in clinical studies and were monitored thereafter. The majority $(71.1 \%)$ of patients received the BSA-adapted dosage of $375 \mathrm{mg} / \mathrm{m}^{2}$, whereas $28.9 \%$ received fixed doses (10 patients: $300 \mathrm{mg}$ and 3 patients: $1,000 \mathrm{mg}$ ). Of note, $37.8 \%$ of patients were treatment naive without previous immune therapy treatment. Among previous therapies, azathioprine, cyclophosphamide, and interferon-beta were most frequent. The washout period was adapted according to the general guidelines, and lymphocyte counts were normal before starting the new therapy. Only patients with no other concomitant immunosuppressive therapy have been included. For 37 patients, we recorded at least 1 event (when $\mathrm{CD} 19^{+}$ cells surpassed $1 \%$ of lymphocytes after $\mathrm{CD} 19^{+}$cell depletion); in total, 87 treatment cycles could be used for data analysis in our cohort. Averaged $\mathrm{CD} 19^{+}$cells first reached $1 \%$ after 253 days or 8.3 months (mean \pm SD: $253.37 \pm 81.67$ ) after last treatment. Earliest repopulation occurred after 108 days (3.6 months), and latest repopulation after 554 days (18.2 months).

\section{BSA-dependent B-cell recovery after treatment with $375 \mathrm{mg} / \mathrm{m}^{2}$}

A total of 305 observations had complete information without missing BSA values. This constituted data from 29 patients who had collectively experienced a total of 79 events. The BSA-adapted dosage of $375 \mathrm{mg} / \mathrm{m}^{2}$ resulted in a greater dose for patients with a larger BSA (patient dosages ranged from 574 to $975 \mathrm{mg}$ ). Underlying diagnosis did not predict the time until B-cell recovery. However, patients with a larger BSA were at significantly higher risk of experiencing repopulation than those with a smaller BSA (HR 1.015 per $\mathrm{cm}^{2}$, CI $1.003-1.028, p<0.05$, fully adjusted Cox proportional hazards regression model; figure $1 \mathrm{~B}$, table e-1, links.lww.com/ NXI/A45: model 7 and table e-2), although they received an adapted dose of $375 \mathrm{mg} / \mathrm{m}^{2}$. The fully adjusted random effects model revealed that with every $10 \mathrm{~cm}^{2}$ increase in the BSA, the time until CD19 cell repopulation was reduced by 14 days $(\mathrm{B}=-1.389$, standard error $[\mathrm{SE}]=0.554, p<0.05$; table e-3: model 7). The Kaplan-Maier curves of the 1st and 4th quartiles of the BSA underline this observation (HR 30.5, CI 11.43-81.44, $p<0.001$, Log-rank [Mantel-Cox] test; figure 1C) by showing a faster B-cell repopulation for patients with a larger BSA. This phenomenon was also reflected in longer treatment intervals in patients with a small BSA and shorter treatment intervals in patients with a large BSA (figure 2A).
Table 1 Baseline cohort characteristics

\begin{tabular}{|c|c|}
\hline Patient characteristics & $\begin{array}{l}\text { Patients } \\
(\mathrm{N}=45)\end{array}$ \\
\hline Rituximab, $\mathbf{n}$ & 42 \\
\hline Ocrelizumab, $\mathbf{n}$ & 3 \\
\hline Age at the first dose $(y \pm S D)$ & $44.5 \pm 15.0$ \\
\hline Female, $\mathbf{n}(\%)$ & $28(62.2)$ \\
\hline No previous disease-modifying therapy, $n$ (\%) & $17(37.8)$ \\
\hline Previous disease-modifying therapy, $\mathbf{n}(\%)$ & $28(62.2)$ \\
\hline Azathioprine & $11(24.4)$ \\
\hline Interferon beta-1a/1b & $10(22.2)$ \\
\hline Cyclophosphamide & $8(17.8)$ \\
\hline Fingolimod & $7(15.6)$ \\
\hline Natalizumab & $6(13.3)$ \\
\hline Mycophenolate mofetil & $5(11.1)$ \\
\hline Dimethyl fumarate & $4(8.9)$ \\
\hline Glatiramer acetate & $3(6.7)$ \\
\hline Mitoxantrone & $3(6.7)$ \\
\hline Cyclosporine & $2(4.4)$ \\
\hline Infliximab & $2(4.4)$ \\
\hline Methotrexate & $1(2.2)$ \\
\hline BSA-adapted dose 375 mg/m², n (\%) & $32(71.1)$ \\
\hline Average dose (mg) & $\begin{array}{l}633.3 \pm \\
235.5\end{array}$ \\
\hline Fixed dose, $\mathbf{n}(\%)$ & $13(28.9)$ \\
\hline $300 \mathrm{mg}$ & $10(22.2)$ \\
\hline $1,000 \mathrm{mg}$ & $3(6.7)$ \\
\hline $\begin{array}{l}\text { No. of events (CD19+ cells first surpass } 1 \% \text { after } \\
\text { depletion) of all observations }\end{array}$ & 87 of 373 \\
\hline Time when $\mathrm{CD} 19^{+}$cells first surpass $1 \%, d$ & $251.2 \pm 83.6$ \\
\hline 25th percentile & 204.25 \\
\hline Median & 245 \\
\hline 75th percentile & 302 \\
\hline $\mathrm{CD}^{\prime} 9^{+}$cells before the first treatment $(\%)(n=18)$ & $11.3 \pm 5.8$ \\
\hline
\end{tabular}

Abbreviation: BSA = body surface area.

Patients who received either rituximab or ocrelizumab in our neurologic clinic.

Data are presented as mean $\pm S D$, unless otherwise indicated.

Several different equations for predicting the BSA from measurements of height and weight have been derived (e.g., Dubois, Haycok, or Mosteller). The correlation between all the formulas is generally high. The Dubois equation is most frequently used, although specific recommendations for calculating the BSA are not included in neurologic medical 

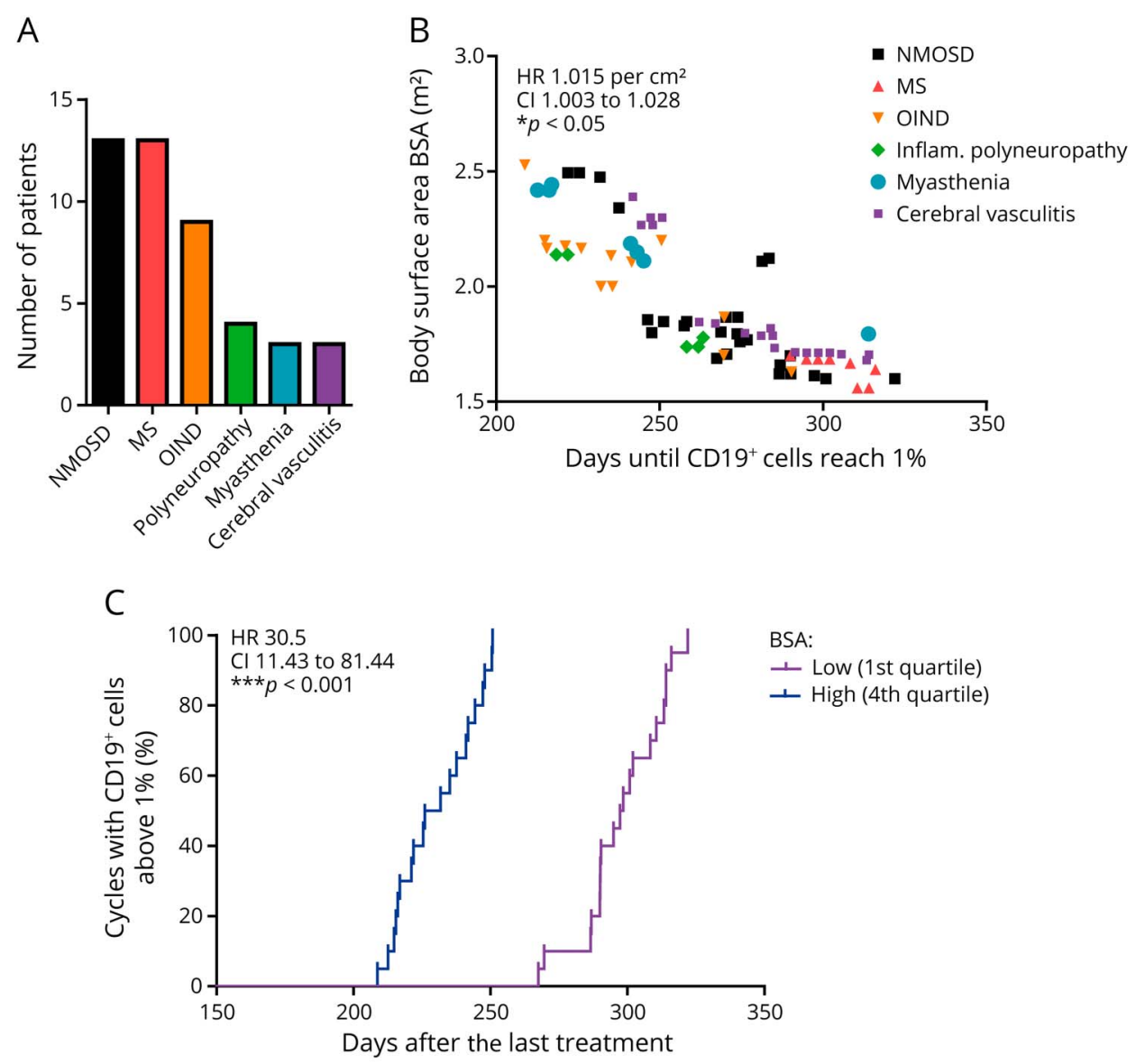

Cycles at risk:

Low BSA (1st quartile) $20 \quad 20 \quad 10 \quad 0$

High BSA (4th quartile) $20 \quad 3 \quad 0$

(A) Disease spectrum of patients who received rituximab or ocrelizumab. Other inflammatory neurologic diseases (OIND) included neurosarcoidosis, rheumatoid meningoencephalomyelitis, and neurolupus disease. (B) The time until $\mathrm{CD} 19^{+}$cells are first detected above $1 \%$ negatively correlates with the BSA in patients who already received a BSAadapted dosage of $375 \mathrm{mg} / \mathrm{m}^{2}$ ( $\mathrm{n}=79$ treatment cycles from 29 patients were included, ${ }^{*} p<0.05$, fully adjusted Cox proportional hazards regression model). (C) Survival analysis for the 1st and 4th quartiles of the BSA for surpassing $1 \%$ CD19 ${ }^{+}$cells with significant differences (*** $p<0.001$, log-rank [Mantel-Cox] guidelines. However, it has been previously suggested that Dubois might lead to lower values than Mosteller in patients with large height and weight. ${ }^{10}$ To address this issue, we compared resulting BSA-adjusted dosages calculated using the Dubois or Mosteller equation to determine the BSA (figure 2B). The resulting dosage differs for patients with a high BSA (4th quartile) also in our cohort (871.9 $\pm 10.22 \mathrm{vs}$ $896 \pm 11.67 \mathrm{mg}, p<0.001$, paired $t$ test). For patients with a low BSA, there was no significant difference.

\section{No influence of age, sex, pretreatment, CSF, or white blood cell counts on B-cell recovery}

The age of patients did not show a conclusive relationship with repopulation of $\mathrm{CD} 19^{+} \mathrm{B}$ cells (figure $3 \mathrm{~A}$, tables e- 1 and e-2, links.lww.com/NXI/A45). However, although patients who received any immune therapy before B-cell depletion (HR 1.444, CI 0.918-2.272, $p>0.05$, Cox proportional hazards regression models; figure $3 \mathrm{~B}$, table e- 1 : model 7 , and table e-2: model 6) and male patients (HR 1.453, CI 0.809-2.607, $p>0.05$, Cox proportional hazards regression models; figure $3 \mathrm{C}$ ) tended to repopulate earlier, a significant effect might not have been achieved because of the limited event numbers in the fully adjusted models (see also random effects model, tables e-3 and e-4). Leukocyte and lymphocyte counts did not show any correlation with B-cell repopulation behavior. We divided patients into 2 groups: (1) patients who experienced on at least 1 occasion leukopenia (leukocytes < $3,500 / \mu \mathrm{L}$ ) or lymphopenia (lymphocytes $<1,000 / \mu \mathrm{L}$ ) and (2) patients who never had a reduced leukocyte or lymphocyte count throughout the B-cell depletion period. We found no differences between patients who had experienced leukopenia or lymphopenia and the remaining patients regarding days until B-cell repopulation (258.2 \pm 13.98 days [1], $251.3 \pm$ 11.15 days [2], $p=0.73$, unpaired 2 -sided students $t$ test; figure $3 \mathrm{D})$. Neither the presence of oligoclonal bands nor the absolute cell count in the CSF after diagnosis but before the first treatment showed any correlation with B-cell recovery (figure $3 \mathrm{E}$ ). The presence of aquaporin-4 antibodies of patients with NMOSD also did not show any correlation, and B-cell counts before treatment did not correlate with B-cell repletion kinetics $(\mathrm{B}=-3.688, \mathrm{SE}=2.513, p=0.142$, table e-5). In addition, absolute cell counts for $\mathrm{T}$ lymphocytes and natural killer cells did not change over time after $\mathrm{CD} 20^{+}$cell depletion (figure 3F). 

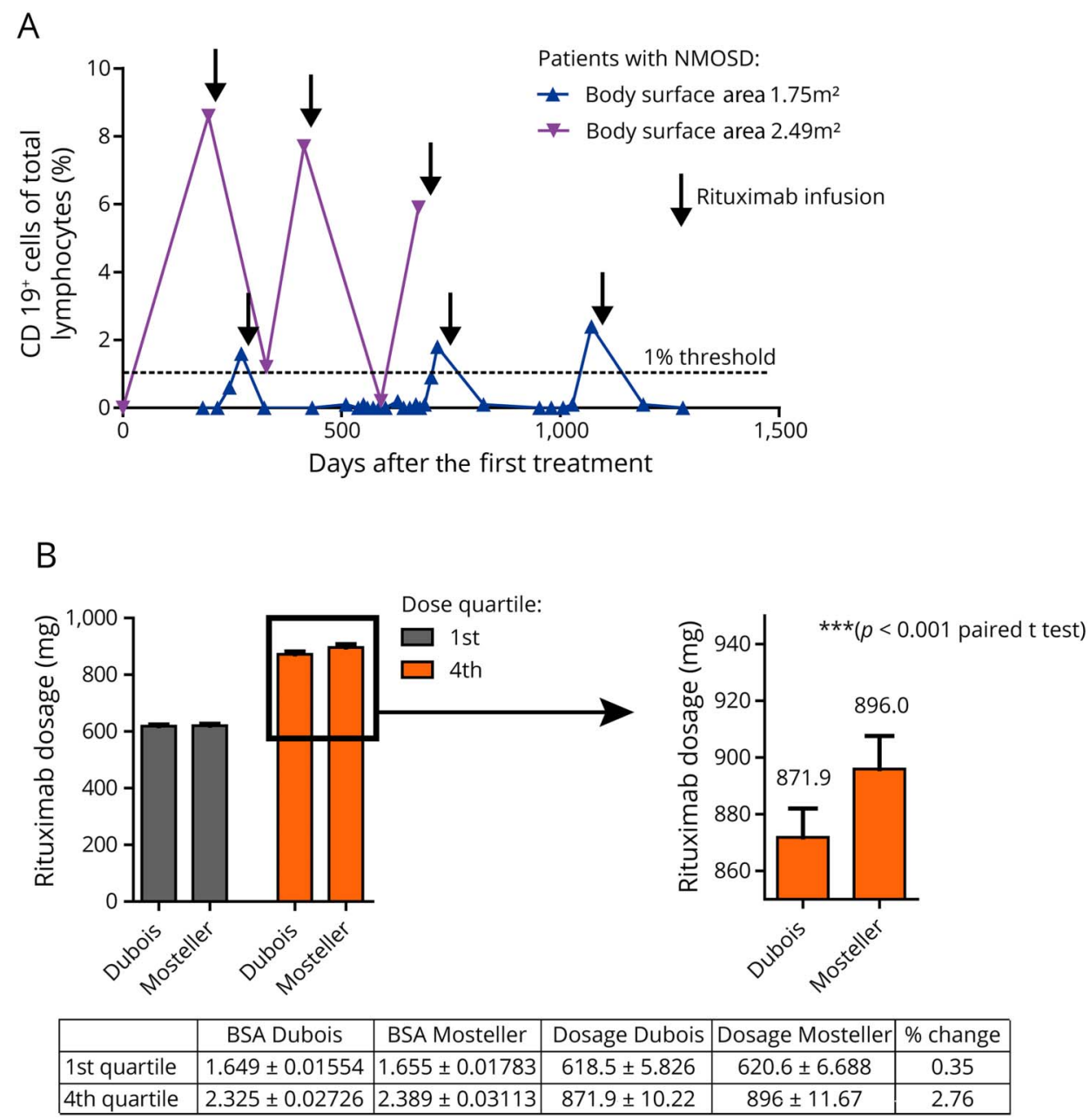

(A) Comparison of $\mathrm{CD} 19^{+}$cell recovery in 2 patients with high and low BSA over several treatment cycles. (B) The BSA $\left(\mathrm{m}^{2}\right)$ calculated using the Dubois formula significantly underestimates dosages for our patients with a high BSA (4th quartile, $871.9 \pm 10.22$ vs $896 \pm$ $11.67 \mathrm{mg}, p<0.001$, paired $t$ test).
Results were not caused by outliers with a smaller or larger BSA but appeared to be robust against values from extreme ends (i.e., lower and upper 5\% quantiles). The unadjusted effects of previous therapy and sex disappeared in the models adjusted for the BSA. This change likely was based on a reduction in the sample size rather than adjustment. Additional tests revealed that patients with missing values on the BSA ran a lower risk of the event than patients with nonmissing values (table e-2, links.lww.com/NXI/A45). The limited statistical power and model fit do not yet permit conclusive statements on the remaining risk factors.

\section{Intraindividual B-cell repopulation after multiple rituximab treatment cycles}

Several patients received more than 1 rituximab treatment cycle. In total, we could identify 18 patients who had sufficient data to compare B-cell repopulation events over time in the same individual. As depicted in figure 4A, there was no clear pattern observed in the B-cell recovery after the first and last documented rituximab treatment $(248.9 \pm 13.5$ days after the first rituximab treatment, $256.5 \pm 15.6$ days after the last rituximab treatment, $p=0.71$, unpaired 2-sided Student $t$ test). For 2 patients, B-cell recovery (surpassing $1 \%$ of $\mathrm{CD} 19^{+}$ cells) could be analyzed for up to 8 treatment cycles (see 1 example in figure $4 \mathrm{~B}$ ).

\section{Discussion}

The efficacy of B-cell depletion, especially in progressive MS, has recently drawn interest toward the role of B lymphocytes in pathology and their relevance as therapeutic targets, as well as their response to treatment with disease-modifying drugs such as alemtuzumab and dimethyl fumarate. In our study, factors that influence the repopulation of B cells in neurologic patients after B-cell depletion were analyzed. Whereas obvious parameters such as age, CSF characteristics, and leukocyte counts were not involved in the interindividual variability of B-cell recovery, we identified the risk of a larger BSA for an earlier repopulation of B cells and thus potential disease activity. A systematic underestimation of rituximab dosage calculation based on the widely used Dubois equation in patients with a high BSA was identified as an explanation. Calculating the BSA with the 
Figure 3 Age, pretreatment, sex, and leukopenia do not influence $C D 19^{+}$cell repopulation
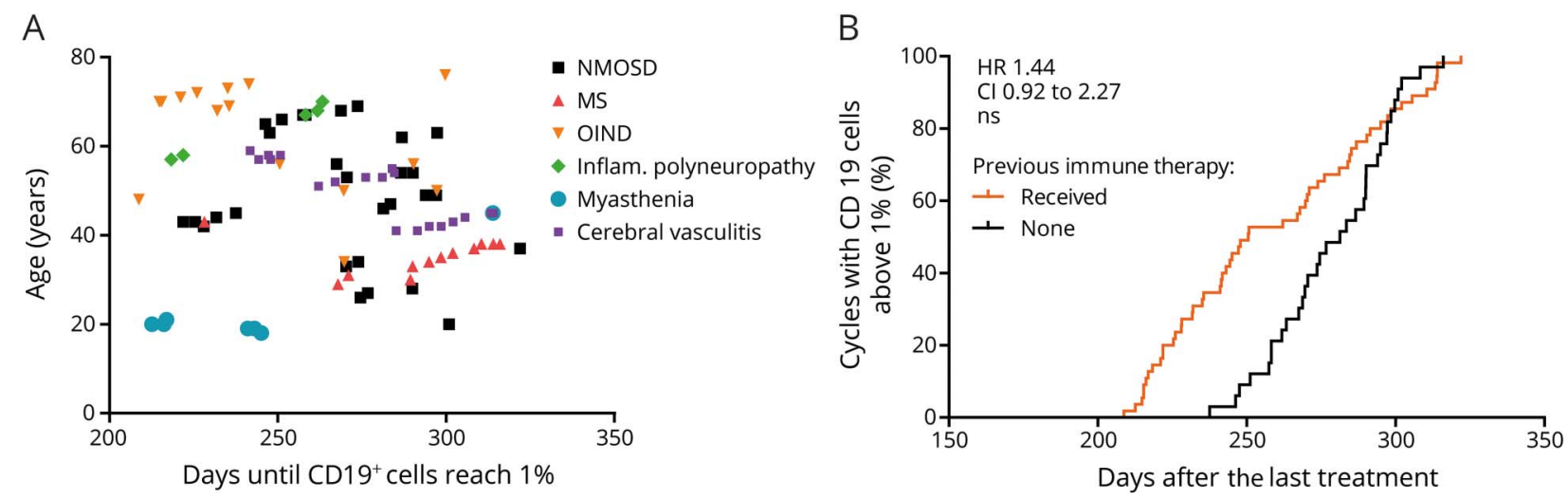

Cycles at risk:

$\begin{array}{lllll}\text { Previous therapy } & 54 & 29 & 9 & 0 \\ \text { No previous therapy } & 33 & 31 & 5 & 0\end{array}$

C

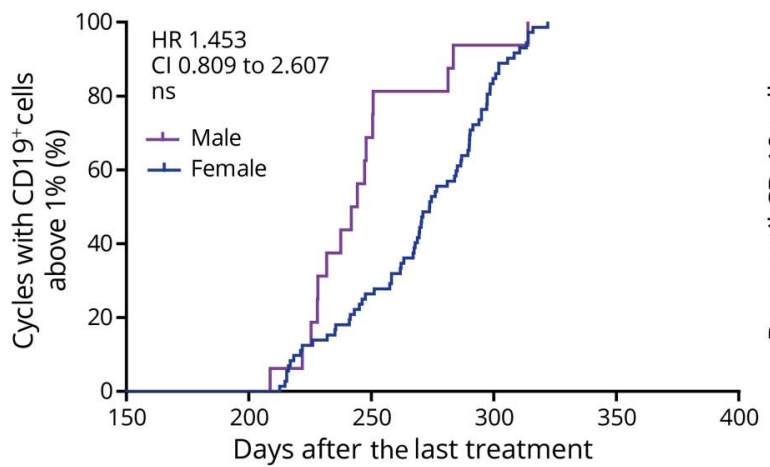

D

Cycles at risk:

$\begin{array}{lrrrr}\text { Male } & 16 & 6 & 2 & 0 \\ \text { Female } & 71 & 54 & 12 & 0\end{array}$
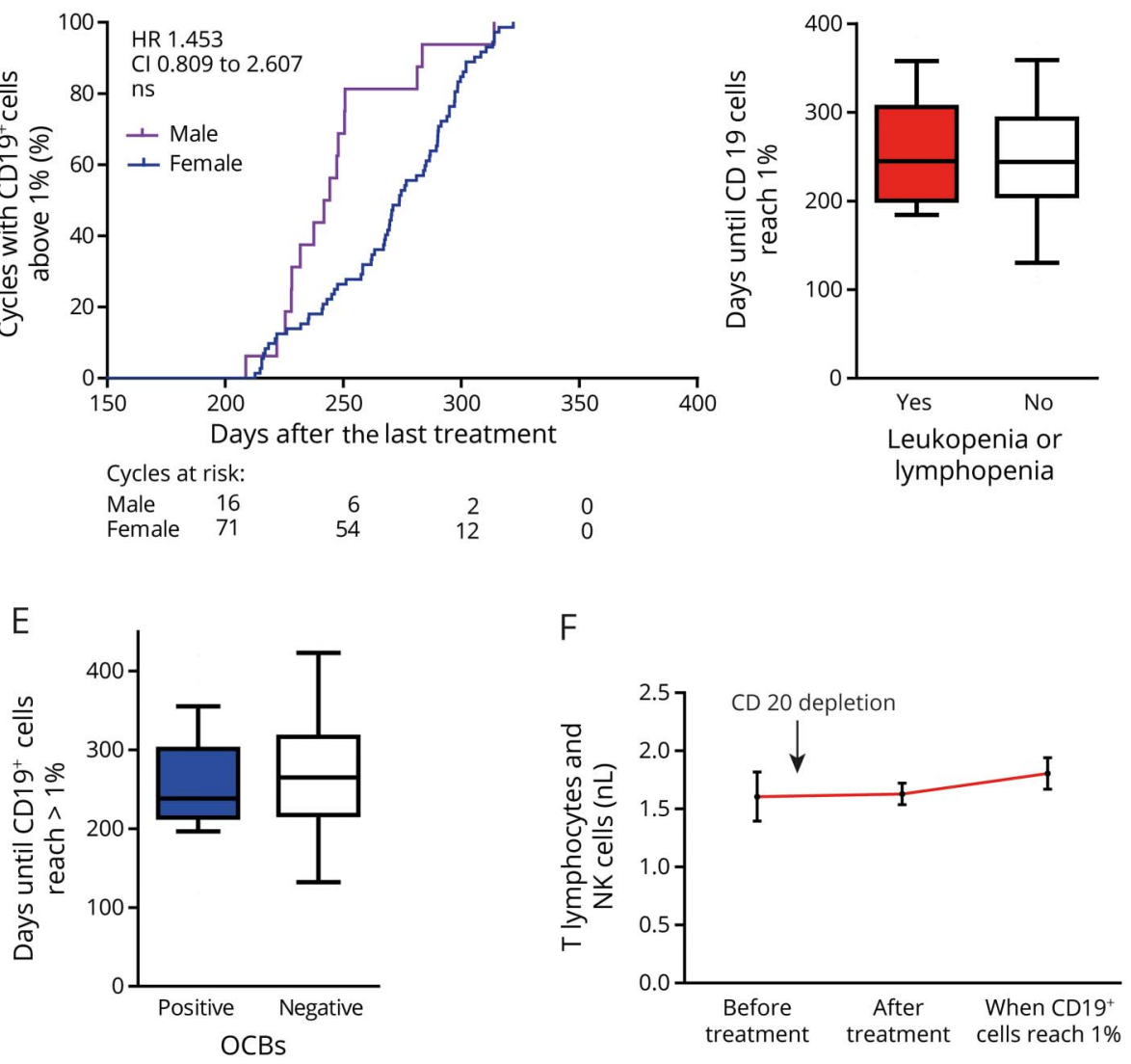

(A) Age, (B) pretreatment, (C) sex ( $n=87$ treatment cycles from 37 patients, HR calculated from fully adjusted Cox proportional hazards regression model, table e-2, links.IwW.com/NXI/A45), and (D) absolute lymphocyte or leukocyte counts ( $p=0.73$, unpaired 2-sided Student $t$ test) or the presence of oligoclonal bands (OCBs) in the CSF ( $E, p=0.41$, unpaired 2-sided Student $t$ test) do not influence the time until CD19+ $9^{+}$cells reach $1 \%$ of lymphocytes. The box-and-whisker plot indicates the median value (center line), the 25th-75th percentiles (box), and the 10th-90th percentiles (whiskers). (F) Absolute counts of T lymphocytes and natural killer cells did not significantly change in our cohort (mean $\pm \mathrm{SEM}$, one-way ANOVA with the Bonferroni multiple comparison test, $p=0.56$ ) over time after CD20 depletion.

Mosteller equation partially overcomes this effect. However, the use of the arbitrary dose of $375 \mathrm{mg} / \mathrm{m}^{2}$ is not sufficient but should be increased especially for patients with a high BSA.

It is important to not miss the time point of B-cell repopulation, as this is most likely linked to resurging disease activity, at least in patients with MS and neuromyelitis optica (NMO). ${ }^{11,12}$ Because of the large intraindividual variation of B-cell repopulation, which has also been described for pediatric patients with $\mathrm{NMO},{ }^{12}$ close monitoring of $\mathrm{B}$ cells is recommended with special attendance to high BSA patients to not miss the early repopulators-the lowest interval was 108 

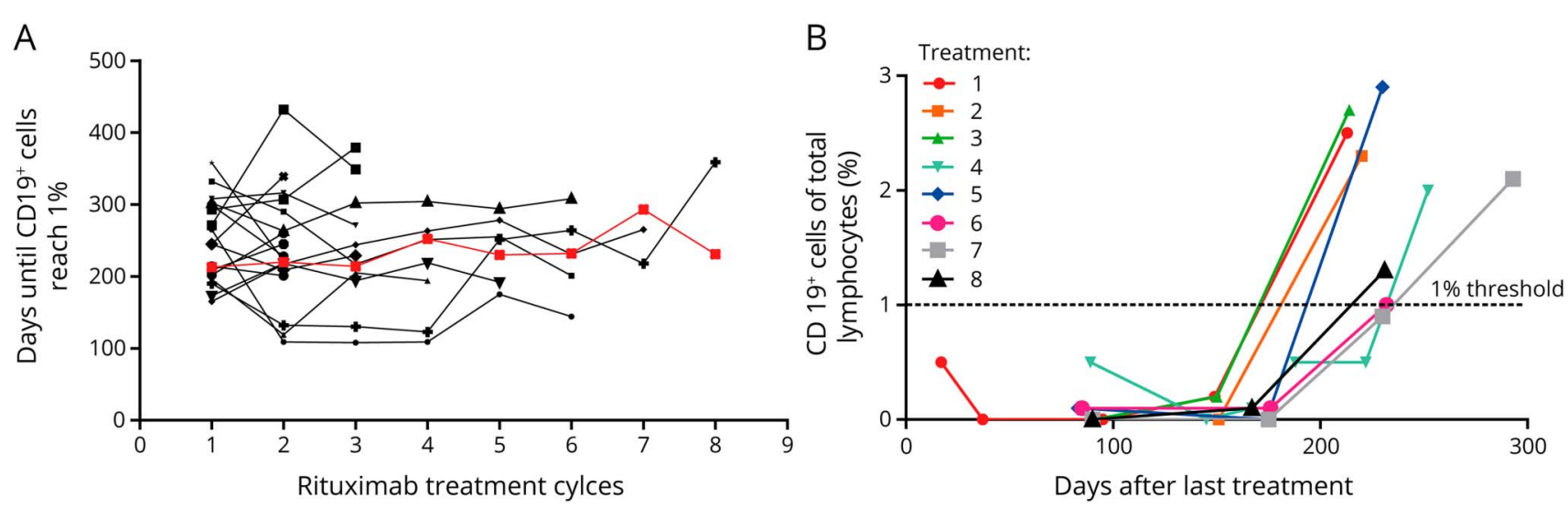

(A) Comparison of time until CD19+ cells were first detected above $1 \%$ after repetitive rituximab cycles in the same patients does not reveal any significant differences over time. (B) CD19+ cell repopulation of one of the patients from (A) (red line) in 8 rituximab treatment cycles.

days (3.6 months) in our cohort. We propose to monitor those patients initially after 2 and 4 months and biweekly to every 4 weeks thereafter. Patient-adjusted treatment intervals decrease potential side effects (e.g., infusion reactions), decrease patient efforts, and save costs as $B$ cells on average repopulate after 8.3 months instead of 6 months (according to the treatment regimen with fixed doses).

Other factors such as age, sex, underlying diagnosis, and pretreatment with other immunosuppressive drugs did not show a significant influence on B-cell repopulation. Small effects might have been overlooked because of the limited number of analyzed events. In male patients and patients with pretreatment, B cells tended to reappear sooner. We could not confirm the association between leukopenia and prolonged recovery of $\mathrm{B}$ cells as suggested before. ${ }^{13}$ The presence or absence of oligoclonal bands in the CSF also did not show any correlation. Concomitant leukopenia and/or lymphopenia were not associated with an impaired B-cell repopulation behavior in our cohort. Also, the repeated application of rituximab in our patients did not lead to a habituation effect of B-cell recovery. Besides, the overall efficacy and safety of the treatment was good with no severe adverse events or clinical relapses in all patients during the study, in line with existing clinical data.

Randomized controlled trials assessing the efficacy and safety of different dosage protocols for neurologic disorders are mostly lacking. In a study with patients with NMO, the duration of depletion was dose dependent as indicated by a repopulation time of 184 days with $1,000 \mathrm{mg}$ vs 99 days with $100 \mathrm{mg}^{6}$ The widely used BSA-adapted dosage of $375 \mathrm{mg} / \mathrm{m}^{2}$ was first introduced in early phase I lymphoma trials ${ }^{14,15}$ failing to demonstrate a clear relationship between the dose intensity and tumor response. The original regimen of ritux$\mathrm{imab}\left(375 \mathrm{mg} / \mathrm{m}^{2}\right.$ per week for 4 weeks) in adult neurology was therefore mainly based on empirical concerns. Data from rheumatoid arthritis studies favor a high-dose rituximab protocol using 2 cycles of $1,000 \mathrm{mg}$, while optimal treatment paradigms have not yet been defined. ${ }^{16,17}$ It should be kept in mind that necessary dosages of B cell-depleting antibodies will most likely depend on the concentration and effect in the target organ itself to target tissue-resident B cells. Lymph node biopsies performed in lymphoma patients show incomplete depletion ${ }^{18}$; moreover, the functional properties of the remaining B cells may change. ${ }^{19}$ However, in patients with MS, rituximab was shown to deplete B cells from the CSF and supposedly also from brain tissue, ${ }^{20,21}$ while this direct CNS effect is probably limited based on the fact that rituximab concentration in the CSF reaches $2 \%$ of serum values. ${ }^{22}$

Future investigations using B cell-depleting therapies in neuroimmunologic diseases should not only address the optimal dosing protocol based on the clinical efficacy and safety but also assess the use of novel biomarkers beyond measuring CD19 ${ }^{+}$ $\mathrm{B}$ cells in the peripheral blood. Potentially interesting B-cell subtypes are memory and effector B cells (e.g., CD $27^{+}$cells, but also $\mathrm{CD}^{2} 7^{-} \mathrm{IgM}^{-} \mathrm{IgD}^{-}$memory cells, late-stage lineage plasmablasts, or increasingly acknowledged cytokine-producing $\mathrm{B}$ cells). Furthermore, gene polymorphisms in the FCGR3A gene encoding the Fc $\gamma$ RIIIa ${ }^{18}$ have been suggested to predict the efficacy of B cell-targeted therapies while these findings have not yet been transferred to neuroimmunologic patients.

\section{Author contributions}

Erik Ellwardt: designed the study, performed data analysis, and wrote the manuscript. Lea Ellwardt: performed statistical analysis. Stefan Bittner: designed the study and wrote the manuscript. Frauke Zipp: designed the study, evaluated data, and wrote the manuscript.

\section{Acknowledgment}

The authors thank Cheryl Ernest for proofreading and editing the manuscript. 


\section{Study funding}

This work was supported by the German Research Council (DFG, CRC-TR-128).

\section{Disclosure}

E. Ellwardt and L. Ellwardt report no disclosures. S. Bittner has received consultation funds and travel compensation from Biogen Idec, Sanofi-Genzyme, Roche, Novartis, and Merck Serono. F. Zipp received travel funding from Teva, Novartis, Merck Serono, Bayer, Biogen Idec, Ono Pharma, Genzyme, Sanofi-Aventis, and Octapharma; received research support from Teva, Novartis, Merck Serono, Bayer, DFG, BMBF KKNMS, PCORI PRAG-MS, and Progressive MS Alliance; received consultation funds from Biogen Idec Germany, Ono Pharma, Genzyme, Sanofi-Aventis, and Octapharma; and consulted for Teva, Merck Serono, Novartis, Bayer Healthcare, Biogen Idec Germany, Ono Pharma, Genzyme, SanofiAventis, and Octapharma. Full disclosure form information provided by the authors is available with the full text of this article at Neurology.org/NN.

Received December 22, 2017. Accepted in final form March 22, 2018.

\section{References}

1. Hauser SL, Bar-Or A, Comi G, et al. Ocrelizumab versus interferon Beta-1a in relapsing multiple sclerosis. New Engl J Med 2017;376:221-234.

2. Hauser SL, Waubant E, Arnold DL, et al. B-cell depletion with rituximab in relapsing-remitting multiple sclerosis. New Engl J Med 2008;358:676-688.

3. Damato V, Evoli A, Iorio R. Efficacy and safety of rituximab therapy in neuromyelitis optica spectrum disorders: a systematic review and meta-analysis. JAMA Neurol 2016; 73:1342-1348

4. Pellkofer HL, Krumbholz M, Berthele A, et al. Long-term follow-up of patients with neuromyelitis optica after repeated therapy with rituximab. Neurology 2011;76: 1310-1315.

5. Yang CS, Yang L, Li T, et al. Responsiveness to reduced dosage of rituximab in Chinese patients with neuromyelitis optica. Neurology 2013;81:710-713.
6. Greenberg BM, Graves D, Remington G, et al. Rituximab dosing and monitoring strategies in neuromyelitis optica patients: creating strategies for therapeutic success. Mult Scler 2012;18:1022-1026.

7. Kim SH, Kim W, Li XF, Jung IJ, Kim HJ. Repeated treatment with rituximab based on the assessment of peripheral circulating memory B cells in patients with relapsing neuromyelitis optica over 2 years. Arch Neurol 2011;68:1412-1420.

8. Kim SH, Huh SY, Lee SJ, Joung A, Kim HJ. A 5-year follow-up of rituximab treatment in patients with neuromyelitis optica spectrum disorder. JAMA Neurol 2013;70:1110-1117.

9. Jacob A, Weinshenker BG, Violich I, et al. Treatment of neuromyelitis optica with rituximab: retrospective analysis of 25 patients. Arch Neurol 2008;65:1443-1448.

10. Fancher KM, Sacco AJ, Gwin RC, Gormley LK, Mitchell CB. Comparison of two different formulas for body surface area in adults at extremes of height and weight. J Oncol Pharm Pract 2016;22:690-695.

11. Stuve O, Leussink VI, Frohlich R, et al. Long-term B-lymphocyte depletion with rituximab in patients with relapsing-remitting multiple sclerosis. Arch Neurol 2009; 66:259-261.

12. Nosadini M, Alper G, Riney CJ, et al. Rituximab monitoring and redosing in pediatric neuromyelitis optica spectrum disorder. Neurol Neuroimmunol Neuroinflamm 2016; 3:e188.

13. Radaelli M, Moiola L, Sangalli F, et al. Neuromyelitis optica spectrum disorders: longterm safety and efficacy of rituximab in Caucasian patients. Mult Scler 2016;22: 511-519.

14. Maloney DG, Grillo-Lopez AJ, White CA, et al. IDEC-C2B8 (Rituximab) anti-CD20 monoclonal antibody therapy in patients with relapsed low-grade non-Hodgkin's lymphoma. Blood 1997;90:2188-2195.

15. Maloney DG, Liles TM, Czerwinski DK, et al. Phase I clinical trial using escalating single-dose infusion of chimeric anti-CD20 monoclonal antibody (IDEC-C2B8) in patients with recurrent B-cell lymphoma. Blood 1994;84:2457-2466.

16. Buch MH, Smolen JS, Betteridge N, et al. Updated consensus statement on the use of rituximab in patients with rheumatoid arthritis. Ann Rheum Dis 2011;70:909-920.

17. Bredemeier M, de Oliveira FK, Rocha CM. Low- versus high-dose rituximab for rheumatoid arthritis: a systematic review and meta-analysis. Arthritis Care Res 2014; 66:228-235.

18. Ternant D, Cartron G, Henin E, Tod M, Girard P, Paintaud G. Model-based design of rituximab dosage optimization in follicular non-Hodgkin's lymphoma. Br J Clin Pharmacol 2012;73:597-605.

19. Kamburova EG, Koenen HJ, Borgman KJ, Ten Berge I, Joosten I, Hilbrands LB. A single dose of rituximab does not deplete B cells in secondary lymphoid organs but alters phenotype and function. Am J Transplant 2013;13:1503-1511.

20. Cross AH, Stark JL, Lauber J, Ramsbottom MJ, Lyons JA. Rituximab reduces B cells and $\mathrm{T}$ cells in cerebrospinal fluid of multiple sclerosis patients. J Neuroimmunol 2006; 180:63-70.

21. Martin Mdel P, Cravens PD, Winger R, et al. Depletion of B lymphocytes from cerebral perivascular spaces by rituximab. Arch Neurol 2009;66:1016-1020.

22. Komori M, Lin YC, Cortese I, et al. Insufficient disease inhibition by intrathecal rituximab in progressive multiple sclerosis. Ann Clin translational Neurol 2016;3: $166-179$. 


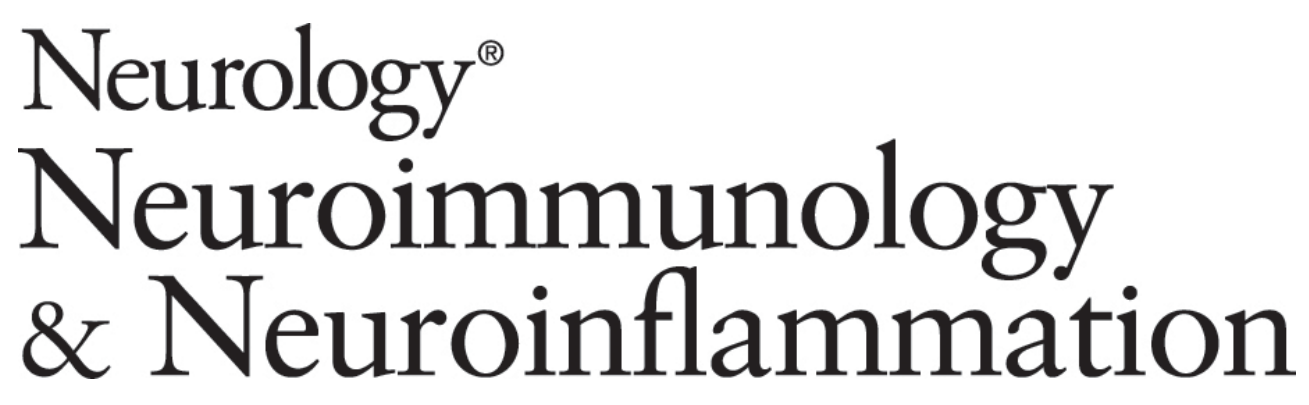

Monitoring B-cell repopulation after depletion therapy in neurologic patients Erik Ellwardt, Lea Ellwardt, Stefan Bittner, et al.

Neurol Neuroimmunol Neuroinflamm 2018;5;

DOI 10.1212/NXI.0000000000000463

This information is current as of April 25, 2018

Neurol Neuroimmunol Neuroinflamm is an official journal of the American Academy of Neurology.

Published since April 2014, it is an open-access, online-only, continuous publication journal. Copyright

Copyright $\odot 2018$ The Author(s). Published by Wolters Kluwer Health, Inc. on behalf of the American

Academy of Neurology.. All rights reserved. Online ISSN: 2332-7812.

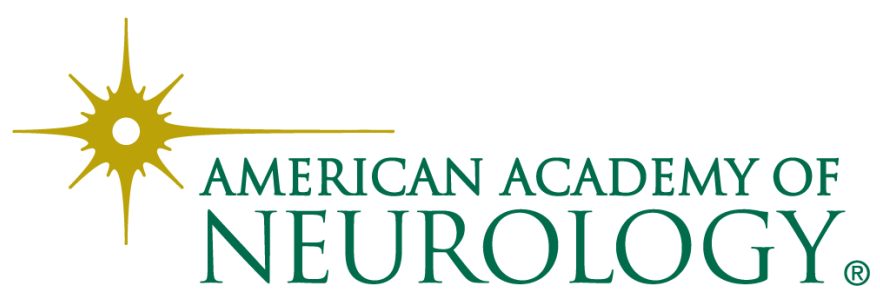




\section{Updated Information \& Services}

References

Citations

Subspecialty Collections

Permissions \& Licensing

Reprints including high resolution figures, can be found at: http://nn.neurology.org/content/5/4/e463.full.html

This article cites 22 articles, 3 of which you can access for free at: http://nn.neurology.org/content/5/4/e463.full.html\#\#ref-list-1

This article has been cited by 7 HighWire-hosted articles: http://nn.neurology.org/content/5/4/e463.full.html\#\#otherarticles

This article, along with others on similar topics, appears in the following collection(s):

All Clinical Neurology

http://nn.neurology.org//cgi/collection/all_clinical_neurology All Demyelinating disease (CNS)

http://nn.neurology.org//cgi/collection/all_demyelinating_disease_cns Autoimmune diseases

http://nn.neurology.org//cgi/collection/autoimmune_diseases

\section{Class III}

http://nn.neurology.org//cgi/collection/class_iii

Multiple sclerosis

http://nn.neurology.org//cgi/collection/multiple_sclerosis

Information about reproducing this article in parts (figures,tables) or in its entirety can be found online at:

http://nn.neurology.org/misc/about.xhtml\#permissions

Information about ordering reprints can be found online:

http://nn.neurology.org/misc/addir.xhtml\#reprintsus

Neurol Neuroimmunol Neuroinflamm is an official journal of the American Academy of Neurology.

Published since April 2014, it is an open-access, online-only, continuous publication journal. Copyright

Copyright $\odot 2018$ The Author(s). Published by Wolters Kluwer Health, Inc. on behalf of the American

Academy of Neurology.. All rights reserved. Online ISSN: 2332-7812.

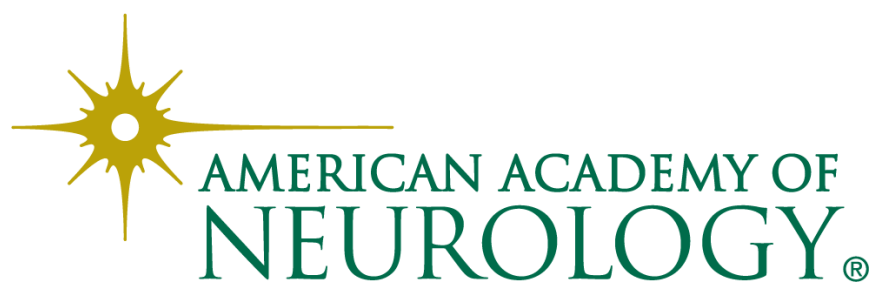

